\title{
РЕГІОНАЛЬНІ УГОДИ ПРО ВІЛЬНУ ТОРГІВЛЮ ЗА УЧАСТЮ УКРАЇНИ: МОЖЛИВОСТІ ТА РИЗИКИ
}

\section{FREE TRADE REGIONAL AGREEMENTS WITH UKRAINE: OPPORTUNITIES AND RISKS}

\author{
Комар Наталія Володимирівна \\ кандидат економічних наук, доцент, \\ Західноукраїнський національний університет \\ ORCID: https://orcid.org/0000-0003-3009-977X \\ Уніят Алла Володимирівна \\ кандидат економічних наук, доцент, \\ Західноукраїнський національний університет \\ ORCID: https://orcid.org/0000-0002-8129-4754
}

Komar Nataliya, Uniyat Alla

West Ukrainian National University

Конкуренція на світових ринках супроводжується розвитком специфічних форм міжнародного регіонального співробітництва - підписання регіональних торговельних угод про ЗВТ. На даний час Україною укладено угоди про вільну торгівлю з Європейською асоціацією вільної торгівлі (ЄАВТ), країнами СНД, а також із Чорногорією, Македонією, Грузією, Азербайджаном, Узбекистаном, Таджикистаном, Туркменістаном. У січні 2016 році набрала чинності Угода про вільну торгівлю між Україною та країнами ЄС, яка забезпечує лібералізацію торгівлі товарами та послугами. 3 моменту підписання Угоди про ЗВТ між Україною та Канадою експорт з Канади в Україну та експорт з України в Канаду зростав щороку, незважаючи на політичну та економічну нестабільність в нашій державі. Нещодавно ратифікована Угода між Україною та Ізраїлем є зеленим «світлом» для зростання експорту України, а також передумовою тісної співпраці у сорерах високих технологій, машинобудування, інвестицій.

Ключові слова: торговельні угоди, СОТ, Зона вільної торгівлі (ЗВТ), ЄС, експортно-імпортні операції.

Конкуренция на мировых рынках сопровождается развитием специфических фрорм международного регионального сотрудничества - подписание региональных торговых соглашений о ЗСТ. В настоящее время Украиной заключены соглашения о свободной торговле с Европейской ассоциацией свободной торговли (ЕАСТ), странами СНГ, а также с Черногорией, Македонией, Грузией, Азербайджаном, Узбекистаном, Таджикистаном, Туркменистаном. В январе 2016 года вступило в силу Соглашение о свободной торговле между Украиной и странами ЕС, которая обеспечивает либерализацию торговли товарами и услугами. С момента подписания Соглашения о ЗСТ между Украиной и Канадой экспорт из Канады в Украину и экспорт из Украины в Канаду рос ежегодно, несмотря на политическую и экономическую нестабильность в нашем государстве. Недавно ратисрицирована Соглашение между Украиной и Израилем является зеленым «светом» для роста экспорта Украины, а также предпосылкой тесного сотрудничества в сферах высоких технологий, машиностроения, инвестиций.

Ключевые слова: торговые соглашения, ВТО, Зона свободной торговли (ЗСТ), ЕС, экспортно-импортные операции.

Growing competition in world markets became prerequisite the development of specific forms of international regional cooperation - signing the regional agreements of FTZ. Because bilateral agreements are much easier and faster for understanding on new rules which are not in WTO. Moreover participants of bilateral agreements can agree on trade liberalization and political concessions in comparison of WTO's ones. Ukraine has so active position on the processes of global and regional integration. The main purpose of the article is to assess the potential opportunities and risks on regional trade agreements signing between Ukraine and countries of Europe, America and Asia. The methodological basis of the article are general scientific and empirical methods of scientific research, such as: historical, systemic, generalization method grouping method, comparative method, quantitative analysis. Ukraine has concluded free trade agreements with the European Free Trade Association (EFTA), the CIS countries, as well as with Montenegro, Macedonia, Georgia, Azerbaijan, Uzbekistan, Tajikistan and Turkmenistan. In January 2016, the Free Trade Agreement between Ukraine and the EU countries entered into force, according to which the partici- 
pants reduce customs duties on mutual trade for 10 years. In parallel, over five years, they have gradually to reduce export duties and subsidies to zero. Undoubtedly, the Agreement signing and FTZ functioning with the EU countries have had an extremely strong impact on the Ukrainian economy, in particular on trade's structure, business climate, investment level, productivity, sectors competition and so on. Since the FTA signing between Ukraine and Canada, exports from Canada to Ukraine and exports from Ukraine to Canada have grown dramatically every year, despite the political and economic instability in our country. The trade and economic activity growth between Canada and Ukraine, according to experts opinion, will contribute Ukraine's transition to a market economy with the protection of property rights, compliance of labor standards, the rule of law and democratic governance. The recently ratified Agreement between Ukraine and Israel is a green light for the growth of Ukraine's exports, as well as a prerequisite for close cooperation in the fields of high technology, engineering and investment.

Keywords: trade agreements, WTO, Free Trade Zone (FTZ), EU, export-import operations.

Постановка проблеми. Кінець XX століття показав, що кожна країна в умовах глобалізацій пов'язана з торговельно-економічними зв'язками. До того ж кількість укладених угод про ЗВТ збільшується. На практиці угоди про ЗВТ називають «регіональним». Така назва використовується лише для протиставлення угодам СOT, а не через прив'язку до якогось конкретного регіону.

Зміст регіональних торговельних угод суттєво змінився, оскільки крім зниження тарифів та скасування нетарифних бар'єрів між країнами, що об'єднались у зону вільної торгівлі, укладені угоди регулюють питання інтелектуальної власності, сталого розвитку, інвестицій, прав споживачів, екологічних стандартів. До того ж країна може бути членом у декількох зонах вільної торгівлі. Кількісне і якісне зростання регіональних торговельних угод з кожним роком набуває все більшої актуальності. Так, за даними СОТ у 1993 році було підписано 37 угод про ЗВТ, а на кінець 2018 року - 467 угод про ЗВТ.

Серед регіональних об'єднань найбільш популярною $€$ зона вільної торгівлі країн $€ C$. Україна є членом Угоди про асоціацію з ЄС. Але поряд 3 цим Україна $є$ учасником угод про ЗВТ з СНД, Грузією, Македонією, Чорногорією, ЄABT, а також нещодавно набули чинності Угоди про ЗВТ з Канадою, Ізраїлем. Низка інших угод про ЗВТ все ще проходять раунди двосторонніх переговорів. Як бачимо Україна намагається займати активну позицію з точки зору лібералізації торговельно-економічних зв'язків між різними країнами світу, не лише країнами європейського континенту, а й Америки, Близького Сходу, Азії. Як показує досвід різних країн, укладені ЗВТ сприяють вільному руху товарів та послуг між країнами, що, своєю чергою, сприяє залученню інвестицій, здешевленню імпорту, розвитку внутрішнього виробництва, інсрраструктури, обміну досвідом і технологіями, забезпечують зайнятість населення, надходження до бюджетів податків та зборів, збереження тісних міждержавних зв'язків.
Саме тому політика України щодо зміни торговельного режиму повинна базуватися на прагматичних оцінках ризиків та можливостей, пов'язаних із прийняттям кожного рішення, що може мати як позитивні, так і негативні наслідки для національної економіки.

Аналіз останніх досліджень і публікацій. Дослідженням інтеграції економіки України у світове господарство шляхом укладання регіональних торговельних угод про вільну торгівлю займалися ряд науковців, такі як, зокрема: Бураковський І.В., Щербата Н.З., Кваша С.М., Клочко В.П., Кауфрман 3., Шнирков О.І., Муравйов В.І., Науменко Н.С., Гужва І.Ю., Гайдуцький А.П., Савельєв Є.В., Іващук І.О., Шаповалова О., Комар Н.В., Сіскос $Є$., Дарвіду К. та ін.

Однак актуальним завданням досі залишається дослідження існуючих угод про вільну торгівлю за участю України, а також оцінка економічних наслідків зокрема від створення регіональних торговельних угод про ЗВТ між Україною та країнами ЄС (т. з. Угода про асоціацію), між Україною та Канадою, а також нещодавно підписаною Угодою про ЗВТ між Україною та Ізраїлем.

Мета та завдання статті. Основною метою статті $€$ оцінювання можливостей та ризиків від створення ЗВТ між Україною та країнами $€ C$, Канадою та Ізраїлем, а також макроекономічних вигод України як від європейського, так і від трансатлантичного, євразійського співробітництва.

Виклад основного матеріалу дослідження. Впродовж 1992-2019 рр. Україна заключила 16 угод про вільну торгівлю 3 45 країнами світу. Так, регіональна торговельна політика України довгий час відрізнялася низьким рівнем диверсифрікації. Основними угодами про вільну торгівлю були угоди - багатостороння угода про СНД та двосторонні угоди про вільну торгівлю між Україною й Азербайджаном, Узбекистаном, Таджикистаном і Туркменістаном. 
Після здобуття Україною незалежності, зовнішньоторговельна політика нашої держави почала диверсиоріковуватись. Так, Україна підписала угоду між Урядом України та Урядом Республіки Грузія від 09.01.1995 р., яка набрала чинності 04.06.1996р., в рамках якої почав функціонувати режим ЗВТ між Україною та Грузією. На даний час існує ЗВТ між обома країнами, але вже на основі міжурядового Протоколу про внесення змін і доповнень до вказаної Угоди від 17.06.2009 р., що пов'язано з виходом Грузії з СНД.

Першою європейською країною, 3 якою український уряд підписав угоду про ЗВТ у 2001 році, була Македонія, що стало передумовою посилення переговорного процесу в напрямку укладання двосторонніх торговельних угод із європейськими країнами-партнерами. Після завершення вступу України до Світової організації торгівлі 18 лютого 2008 року були започатковані переговори в частині створення поглибленої та всеохоплюючої зони вільної торгівлі між Україною та ЄС [12].

Крім того, впродовж 2010-2011 рр. відбувся переговорний процес з такими країнами як Канадою, Ізраїлем, Туреччиною та Сербію. 3 двома останніми країнами переговори ще досі тривають. Слід відмітити, що переговорний процес з Сирією, Сінгапуром розпочався, але на даний час він $є$ «заморожений». В той же час український уряд планує розпочати переговорний процес про створення ЗВТ 3 Ліваном, Марокко, В'єтнамом (рис. 1).

3 вище перелічених укладених торговельних угод, найбільша зона вільної торгівлі (далі 3ВТ) була укладена із Європейським Союзом. Так, 21 березня 2014 року була підписала політична частина асоціації між Україною та країнами ЄС 3 метою подальшого вступу нашої країни в ЄС. Угода про Асоціацію між Україною та $€ С$ була повністю підписана 27 червня 2014 року. 16 вересня 2014 року Угода про асоціацію була одночасно ратифрікована Верховною Радою та Європейським парламентом. 31 листопада 2014 року набуло чинності часткове застосування деяких частин Угоди про асоціацію. Стаття 4 Угоди про асоціацію, у котрій йдеться про встановлення Поглибленої та Всеосяжної Зони Вільної Торгівлі (ПВЗВТ), частково вступила в силу 1 січня 2016 року [4].

У квітні 2014 р. в режимі автономних торговельних преференцій європейська сторона значною мірою лібералізувала митний режим для більшості українських товарів. Так, ЄС повністю скасував ввізні мита для 94,7\% українських промислових товарів, 82,2\% для сільськогосподарської продукції та 83,4\% для харчової продукції. В свою чергу Україна почала скасовувати ввізні

\begin{tabular}{|c|c|}
\hline 1 & $\begin{array}{l}\text { • Угода про ЗВТ України з Грузією (набрала чинності 04.06.1996 р.) } \\
\text { та Македонією (набрала чинності 10.09.2001р.); }\end{array}$ \\
\hline 2 & $\begin{array}{l}\text { - Угода про вільну торгівлю між Україною та державами САВТ } \\
\text { (Швейцарія, Норвегія, Ісландія та Ліхтенштейн) (набрала чинності } \\
\text { 01.06.2012 р.); }\end{array}$ \\
\hline 3 & $\begin{array}{l}\text { - Угода України із країнами Співдружності незалежних держав } \\
\text { (крім Росії, яка з } 1 \text { січня } 2016 \text { року відмовилася виконувати зобов'язання } \\
\text { щодо цієї угоди) (набрала чинності 20.09-09.12.2012 р.); }\end{array}$ \\
\hline 4 & $\begin{array}{l}\text { • Угода про вільну торгівлю між Урядом України та Урядом Чорногорії } \\
\text { (набрала чинності 01.01.2013 р.); }\end{array}$ \\
\hline 5 & $\begin{array}{l}\text { - Угода про вільну торгівлю між Україною та країнами СС } \\
\text { (набрала чинності 01.01.2016 р.); }\end{array}$ \\
\hline 6 & $\begin{array}{l}\text { - Угода про вільну торгівлю між Україною та Канадою } \\
\text { (набрала чинності 01.08.2017 р.); }\end{array}$ \\
\hline 7 & $\begin{array}{l}\text { - У січні } 2019 \text { року був підписана угода між Україною та Ізраїлем про ЗВТ } \\
\text { (набрала чинності 01.01.2021). }\end{array}$ \\
\hline
\end{tabular}

Рис. 1. Хронологія торговельних регіональних угод про ЗВТ між Україною та країнами світу Джерело: складено авторами 
мита на імпорт з $€$. Для окремих, «чутливих» товарних груп Україна застосовує поступове зменшення/скасування ввізних мит для імпорту походженням з ЄС в рамках зони вільної торгівлі між Україною та ЄС протягом перехідних періодів - від 3 до 10 років.

Доступ до Європейський Союзу завдяки скасуванню увізних мит по більшості товарів (99\% тарифнних ліній) $€$ найбільшою перевагою для української сторони. Адже $€ С$ - це найбільший єдиний ринок в світі, який складається 327 країн та охоплює населення, чисельність якого в 11 разів перевищує чисельність населення України [5; 6].

Кількість українських компаній, які здійснюють експорт товарів до держав-членів ЄС постійно зростає: з 10002 компаній в 2014 році до 14545 компаній у 2019 році. 3 початку застосування ПВЗВТ митними органами видано 322 тис. сертифрікатів EUR.1. У 2019 році було видано більше 107 тис. сертифікатів EUR.1, за допомогою яких надаються тарифні преореренції експортерам та імпортерам. Збільшується кількість, орієнтованих на Європу експортерів, які отримали статус уповноваженого експортера та можуть експортувати до ЄС без офрормлення сертифрікату EUR.1. На сьогодні таких підприємств вже 250 [4; 5].

У 2019 р. українські експортери використовували можливості 32 з 40 тарифнних квот (11 3 яких використані у повному обсязі та 2 використані більш ніж на 95\%). Повністю використано 11 тарифрних квот на кукурудзу, пшеницю, ячмінь, мед, цукор, виноградний та яблучний соки, оброблені томати, оброблений крохмаль, вершкове масло, м'ясо птиці та крохмаль.

Україна встановила безмитні тарифні квоти для 3 видів товарів (м'ясо свинини; м'ясо птиці та цукор) та передбачила додаткові обсяги для 2-х 3 них [5; 6].

Іншою перевагою для України після підписання Угоди про асоціацію - рівні умови конкуренції та нарощування обсягів експорту до ЄС. Товарообіг між Україною та $€ С$ після відкриття зони вільної торгівлі постійно зростає. За результатами січня-жовтня 2019 року обсяги зовнішньої торгівлі товарами між Україною та ЄС у порівнянні з аналогічним періодом 2018 року збільшилися на 7,1\%, експорт зріс на 6,1\%, а імпорт на 7,9\%. У порівнянні з періодом до дії зони вільної торгівлі Україна стала набагато більше імпортувати товарів з Хорватії, Італії, Чехії, Румунії, Литви та Ірландії. За 2019 рік Україна найбільше імпортувала товарів з Німеччини, Польщі та Італії. Аналогічна ситуація спостерігається із експортом. Після введення зони вільної торгівлі Україна стала більше експортувати товарів у Бельгію, Ірландію, Мальту, Естонію, Люксембург, Словенію, Нідерланди. В той же час експорт в Португалію, Фінляндію і на Кіпр значно скоротився [5].

Протягом 2017-2018 рр. було прийнято низку важливих законодавчих норм у сорері органічного виробництва, державного контролю, про безпечність та гігієну кормів, про інорормацію для споживачів щодо харчових продуктів, а також розроблено декілька інших важливих норм, зокрема: проект закону щодо вимог до предметів та матеріалів, які контактують 3 харчовими продуктами; щодо відстеження і маркування генетично модифікованих організмів та інші.

Угода створює умови для поглиблення торговельно економічних відносин між ЄС та Україною, тобто резиденти ЄС матимуть право вести бізнес на території України так само, як у свої державах, легко та прозоро. 3 відкриттям ринку пожвавиться імпорт європейських послуг.

Нижчі ціни та вищий рівень життя в Україні дасть змогу знизити тарифні ставки на імпорт з ЄС. Це призведе до збільшення імпорту 3 $\epsilon C$, що забезпечить більш широкий вибір для споживачів та зниження цін. Виробники в Україні отримають доступ до широкого спектру більш дешевих промислових товарів, комплектуючих та обладнання. Крім того, кращі стандарти охорони здоров'я та безпечності продукції також будуть вигідними для українських споживачів, оскільки для них буде гарантована якість товарів, що продаються, а також більша безпечність для всіх [6].

Переговорний процес 3 Канадою завершився підписанням канадсько-української Угоди про вільну торгівлю, яка набула чинності 1 серпня 2017 р. Основною метою якої було створення нових торгових та комерційних можливостей для канадських та українських компаній шляхом покращення умов доступу на ринок, включаючи скасування тарифів.

Після набуття чинності Угоди уряд Канади негайно ліквідував митні збори для 26,5\% своїх тарифрних ліній, в результаті чого 98,1\% тарифних ліній Канади були безмитними для імпорту з України.

Слід зазначити, імпортні тарифри зазнали істотного зниження на такі товари з України як взуття (середній застосовуваний тариф знизився з 9,7\% до 0\%), тваринні або рослинні жири й олії (з 7\% до 0\%), текстиль та одяг (з 4,9\% до 0\%), сиру шкіру, шкіру та хутро (з 3,1\% до 0\%), дерево та вироби з дерева (з 2\% до 0\%), пластмасу (з 1,7\% до 0\%). 
В той же час відбуватиметься поступове скасування імпортних тарифів на певні транспортні засоби 3 України до $0 \%$ за 7-річний перехідний період, іншими словами до 2024 року. Крім того, залишається незмінна глобальна тарифрна квота на деякі сільськогосподарські продукти (птицю, молочні продукти, яйця, пшеницю, ячмінь тощо).

Україна у свою чергу ліквідувала митні збори для 34,7\% тарифних ліній, і в цілому 72,6\% тарифрних ліній України стали безмитними для імпорту з Канади.

Найбільше зниження імпортних тарисрів в Україні, після набрання чинності угоди про ЗВТ між нашою державою та Канадою у 2017 році, відбулося на заготовки з овочів, фррукти, горіхи, злаки та борошно, какао та кондитерські вироби, напої, одяг та текстиль, мило та косметику, крупи тощо.

Решта імпортні тарифи знижуватимуться поступово через 3, 5 та 7 років. Зокрема, у 2020 році Україна мала скасувати 428 імпортних тарифрів $(4,1 \%$ від загальної кількості тарифрних ліній). У 2022 році передбачається скасувати 1768 імпортних тарифрів (16,9\% від загальної кількості тарифнних ліній), у 2024 - відповідно 570 (5,4\%). Як результат, у 2024 році 99\% український тарифр буде звільнений від сплати мита для канадського імпорту, а саме всі вироблені товари та більшість сільськогосподарських продуктів.

Близько 1\% імпортних ліній України на деякі сільськогосподарські продукти з Канади (101 тарисна лінія) будуть обкладені митом, зокрема на такі товари: живі тварини, продукти тваринного походження, овочі, рослинна олія, готові харчові продукти.

Більше того, Україна встановлює тарифнну квоту на деякі продукти зі свинини з Канади (заморожену свинину та деякі свинячі субпродукти та жир). Цукор виключається із режиму ЗВТ.

Двостороння торгівля між Україною та Канадою збільшувалась до початку настання світової економічної кризи 2008-2009 рр., потім частково відновилась в 2010-2013 рр. і знову скоротилась в 2014-2015 рр. через економічну кризу в Україні та військовий конфрлікт у Донбасі. Двостороння торгівля почала зростати в 2017-2018 рр. завдяки економічному відновленню України, а також впровадженню Угоди про вільну торгівлю між нашою державою та Канадою [12].

Так, після підписання Угоди про вільну торгівлю український експорт до Канади стабільно зростав і розширювався набагато швидше порівняно $з$ іншими торговими партнерами - зріс на $70 \%$ у 2017 році, 55\% у 2018 році та 9,4\% у 2019 році [12].

Однак, загальний експорт Канади в Україну скоротився протягом 2018-2019 років, причому суттєве падіння майже на $30 \%$ відбулося у 2019 році через зменшення поставок вугілля з Канади.

В той же час експорт безвугільної галузі Канади в Україну зростав: 390 млн. дол. США у 2016 р. до 115 млн. дол. США у 2019 р., або на 28\% [10].

Уповільнення зростання двостороннього експорту / імпорту Канади та України (без вугілля) у 2019 році відповідало тенденціям української економіки, а саме зниження загального обсягу торгівлі України (зростання експорту, імпорту лише на 5,8\% та 6,3\% відповідно) внаслідок подорожчання української валюти та зниження світових цін на основні українські товари, що експортуються / імпортуються (метали тощо) [11].

Слід зазначити, Україна $€$ ключовим міжнародним партнером для Канади та потенційним ринком для канадських інвестицій в серце Європи. На нашу думку, збільшення благополуччя в результаті залучення канадських інвестицій в Україну створять передумови для збільшення інвестицій в українське бізнес середовище в Канаді, таким чином це сприятиме створенню нових робочих місць та процвітання канадської економіки. Тому саме УкраїнськоКанадський Конгрес повністю підтримує розширення торгової та інвестиційної діяльності між Канадою та Україною у всіх галузях економіки.

Україна, як ми вже зазначали, крім європейського та трансатлантичного напрямків співробітництва, веде активну позицію щодо співпраці $з$ країнами Азії. Так, після 7 раундів переговорів, які завершились у березні 2018 року, була підписана 21 січня 2019 року Угода про Зону вільної торгівлі України з Ізраїлем, яка набрала чинності 1 січні 2021 р. Угода дозволить посилити економічні зв'язки між двома країнами, оскільки скасує більшість імпортних мит для них [3].

Так, згідно підписаного договору між Україною та Ізраїлем про ЗВТ Ізраїльський уряд має скасувати імпортні мита для 80\% українських промислових товарів та понад 9\% для сільськогосподарської продукції.

Україна здебільшого експортує до Ізраїлю сільськогосподарську продукцію (зернові культури, насіння, олійні культури та рослини, такі як ріпак та соняшник), в той час як імпортує хімічні продукти, мінеральне паливо, олію та продукти, створені переробкою насти, ядерні реактори та котли, машини, фррукти та горіхи. Тепер Укра- 
їна зможе експортувати свою пшеницю та пшеничну продукцію без сплати імпортного мита.

У свою чергу, Україна має знизити імпортні мита для 70\% ізраїльської промислової продукції та понад 6\% для сільськогосподарської продукції.

Крім того, ЗВТ направлена на створення умов, які мають сприяти збільшенню інвестицій з боку Ізраїлю в IT сферу, сільське господарство, промисловість та інші економічно важливі галузі. В майбутньому планується співробітництво між Україною та Ізраїлем в авіаційній сорері, транспортному машинобудуванні та автомобілебудуванні.

Висновки. Основними перевагами від підписання регіональних торговельних угод для України є наступні: створення українських брендів, які будуть легко упізнаватися в усьому світі; розширення номенклатури товарів та послуг на внутрішньому ринку України; підвищення попиту на вітчизняну продукцію, в тому числі на ринках третіх країн, у зв'язку із впровадження європейських стандартів; поліпшення структури вітчизняного експорту у бік зменшення сировинної складової та збільшення частки високотехнологічних товарів 3 високою долею доданої вартості, виробленої в Україні.

Незважаючи на те, що країни $€ C$, Канада, Ізраїль відкривають українським товарам доступ до їхніх ринків, вітчизняний ринок не може бути повністю відкритим, адже українські виробники не готові до серйозної зовнішньої конкуренції.

Український експорт - це сировинна спрямованість. Аграрна спрямованість (24\% експорту від продажу становить аграрна сировина) не дозволяє виробляти достатньо доданої вартості та робить залежних виробників від кліма- тичних умов, які змінюються по всьому світу. Територія Україна не $є$ виключенням. Альтернативним джерелом доданої вартості для України можуть стати виготовлення обладнання для газодобувної галузі або виробництво вагонів чи просто деталей до автомобілів, а також готові продукти харчування. На даний момент тільки 6\% експорту від сільськогосподарської продукції становлять готові продукти [4].

Інша проблема, яка не дозволяє використовувати всі можливості від ЗВТ - це невирішена війна на Сході України. Затяжна торговельна війна з Росією, яка проявляється у неправомірній забороні транзиту по її території товарів українського походження до третіх сторін, дія ембарго щодо поставок українських продовольчих товарів на території Росії, призвели до різкого скорочення експорту українських товарів до країн СНД (країн Центральної Азії та Закавказзя), до країн Азії.

На сьогоднішній день сучасна митна політика України є недосконалою: - переміщення товарів з приховуванням інформації від фріскальних органів або шляхом контрабанди; велика кількість правопорушень у сфері інтелектуальної власності; - невідповідність існуючої системи митного контролю сучасним стандартам пропускної спроможності; - наявність певних шахрайських і корупційних схем у системі державного управління митною справою; - великий обсяг тінізації зовнішньоекономічної діяльності вітчизняних підприємств.

Отже, крім внутрішньої підтримки для гармонізації законодавства, адаптування стандартів та норм й побудови необхідних інституцій, необхідна зовнішня технічна та фрінансова допомога Україні.

\section{СПИСОК ВИКОРИСТАНИХ ДЖЕРЕЛ:}

1. Зовнішньоекономічна діяльність України. URL: http://www.ukrstat.gov.ua/operativ/menu/menu_u/zed.htm (дата звернення: 15.04.2019).

2. Клочко В.П. Зовнішньоторговельні відносини України в умовах посилення інтеграційних зв'язків. Актуальні проблеми економіки. 2018. № 11. С. 141-155.

3. Україна та Ізраїль підписали Угоду про зону вільної торгівлі, 2019. URL: https://dt.ua/POLITICS/ukrayinata-izrayil-pidpisali-ugodu-pro-zonu-vilnoyi-torgivli300220_.html

4. Zave Kauffman. Ukraine and European Union. URL: http://www.ledalliance.biz/image/art/pdf/ukraine-eu.pdf

5. Бураковський І.В. Оцінка витрат та вигод від укладання Угоди про зону вільної торгівлі між Україною та ЄС. Ін-т екон. дослідж. та політ. консультацій. Київ : К.І.С., 2010. 94 с.

6. Щербата Н.3. Зовнішньоекономічна політика Європейського Союзу в зонах вільної торгівлі : [монографрія]. Луцьк : ВНУ ім. Л. Українки, 2011. 199 с.

7. Кваша С.М. Формування зони вільної торгівлі між Україною та країнами - членами ЄС і можливі наслідки для аграрного сектору / за ред. С.М. Кваші. Київ : IAE, 2014. 56 с.

8. Шнирков О.І., Муравйов В.І. Зони вільної торгівлі на початку XXI століття. Київ : Київський університет, 2013. $399 \mathrm{c}$.

9. Науменко Н.С. Оцінка ефективності запровадження зони вільної торгівлі України з країнами ЄАВТ. Вісник економічної науки України. 2014. № 2. С. 103-106. 
10.Щодо угод про вільну торгівлю (УВT). URL: http://mfa.gov.ua/ua/about-ukraine/economiccooperation/ trade-agreements

11. Перехід на техстандарти ЄС та СОТ до 2020 року. Inside Ukraine. 2015. № 50. URL: http://www.icps.com.ua/ assets/uploads/files/IU_50_ukr_2015_04_09_1271.pdf

12. Гужва І.Ю. Участь України в зонах вільної торгівлі та можливості адаптації ії національної економіки до умов, сформованих унаслідок створення мегарегіональних торговельних блоків. Науковий вісник Міжнародного гуманітарного університету. Серія : Економіка і менеджмент. 2016. Вип. 15. С. 12-16. URL: http://nbuv.gov.ua/UJRN/Nvmgu_eim_2016_15_5

13. Комар Н.В., Гайдуцький А.П. Навчально-методичний комплекс з дисципліни «Євроінтеграція та міжнародне публічне управління» : навчально-методичний посібник. Тернопіль : THEУ, 2020. 175 с.

14. Комар Н.В. Зони вільної торгівлі: еволюція і ефекти для країн-учасниць. Вісник Тернопільського національного економічного університету. 2015. № 1. С. 68-79.

15. Komar N.V., Savelyev E.V., Siscos E., Darvidu K. Greece: a European mechanism of the exit from the crisis. Journal of European Economy. 2019. № 1(68). C. 31-53.

\section{REFERENCES:}

1. Zovnishnoekonomichna diialnist Ukrainy [Foreign economic activity of Ukraine]. URL: http://www.ukrstat.gov.ua/ operativ/menu/menu_u/zed.htm

2. Klochko V.P. (2018) Zovnishnotorhovelni vidnosyny Ukrainy v umovakh posylennia intehratsijnykh zviazkiv. [Foreign trade relations of Ukraine in terms of strengthening integration ties]. Aktualni problemy ekonomiky, no. 11, pp. 141-155. (in Ukrainian)

3. Ukraina ta Izrail pidpysaly Uhodu pro zonu vilnoi torhivli, 2019. URL: https://dt.ua/POLITICS/ukrayina-taizrayil-pidpisali-ugodu-pro-zonu-vilnoyi-torgivli300220_.html

4. Zave Kauffman. Ukraine and European Union. URL: http://www.ledalliance.biz/image/art/pdf/ukraine-eu.pdf

5. Burakovskyj I.V. (2010) Otsinka vytrat ta vyhod vid ukladannia Uhody pro zonu vilnoi torhivli mizh Ukrainoiu ta YeS [Estimation of costs and benefits from the conclusion of the Free Trade Agreement between Ukraine and the EU]. In-t ekon. doslidzh. ta polit. konsultatsij. Kyiv: K.I.S., 94 p. (in Ukrainian)

6. Scherbata N.Z. (2011) Zovnishnoekonomichna polityka Yevropejskoho Soiuzu v zonakh vilnoi torhivli: [monohrafiia]. [Economic policy of the European Union in free trade areas. Lutsk: VNU im. L. Ukrainky, 199 p. (in Ukrainian)

7. Kvasha S.M. (2014) Formuvannia zony vilnoi torhivli mizh Ukrainoiu ta krainamy - chlenamy YeS i mozhlyvi naslidky dlia ahrarnoho sektoru [Formation of a free trade zone between Ukraine and EU member states and possible consequences for the agricultural sector]. Kyiv: IAE, $56 \mathrm{p}$.

8. Shnyrkov O.I., Muravjov V.I. (2013) Zony vilnoi torhivli na pochatku 21 stolittia [Free trade zones at the beginning of the XXI century] Kyiv: Kyivskyj universytet, $399 \mathrm{p}$.

Naumenko N.S. (2014) Otsinka efektyvnosti zaprovadzhennia zony vilnoi torhivli Ukrainy z krainamy [Evaluation of the effectiveness of the introduction of the free trade zone of Ukraine with the EFTA countries]. Visnyk ekonomichnoi nauky Ukrainy, no. 2, pp. 103-106.

9. Schodo uhod pro vilnu torhivliu (UVT). URL: http://mfa.gov.ua/ua/about-ukraine/economiccooperation/ trade-agreements

10. Perekhid na tekhstandarty YeS ta SOT do 2020 roku. Inside Ukraine (2015), no. 50. URL: http://www.icps.com.ua/ assets/uploads/files/IU_50_ukr_2015_04_09_1271.pdf

11. Huzhva I.Yu. (2016) Uchast Ukrainy v zonakh vilnoi torhivli ta mozhlyvosti adaptatsii ii natsionalnoi ekonomiky do umov, sformovanykh unaslidok stvorennia meharehionalnykh torhovelnykh blokiv [Ukraines participation in free trade zones and the possibility of adapting its national economy to the conditions created by the creation of mega-regional trade blocs]. Naukovyj visnyk Mizhnarodnoho humanitarnoho universytetu. Seriia: Ekonomika $i$ menedzhment, vol. 15, pp. 12-16.

12. Komar N.V., Hajdutskyj A.P. (2020) Navchalno-metodychnyj kompleks z dystsypliny «Yevrointehratsiia ta mizhnarodne publichne upravlinnia»: navchalno-metodychnyj posibnyk [Educational and methodical complex on the subject "European integration and international public administration"]: educational and methodical manual. Ternopil: TNEU, $175 \mathrm{p}$.

13. Komar N.V. (2015) Zony vilnoi torhivli: evoliutsiia i efekty dlia krain-uchasnyts [Free trade zones: evolution and effects for participating countries]. Visnyk Ternopilskoho natsionalnoho ekonomichnoho universytetu, no. 1, pp. 68-79.

14. Komar N.V., Savelyev E.V., Siscos E., Darvidu K. (2019) Greece: a European mechanism of the exit from the crisis. Journal of European Economy, no. 1(68), pp. 31-53. 